\title{
Regulation of the Rb gene by normal and mutated RAS, TPA and EGF
}

\author{
SPYROS LINARDOPOULOS ${ }^{1}$ and DEMETRIOS A. SPANDIDOS ${ }^{1,2}$
}

${ }^{1}$ Institute of Biological Research and Biotechnology, National Hellenic Research Foundation, 48 Vas. Constantinou Ave.,
Athens, 11635; ${ }^{2}$ Medical School, University of Crete, Heraklion 71100, Greece

Received February 4, 1994; Accepted February 28, 1994

\begin{abstract}
Complete inactivation of the human retinoblastoma gene is believed to be an essential step in tumorigenesis of several different cancers. Using the plasmid pRbCAT2 that contains the $\mathrm{Rb}$ promoter region was tested for its ability to promote transcription of the bacterial chloramphenicol acetyltransferase (CAT) gene in a transient expression assay. This plasmid was co-transfected in a short term transfections with the plasmids pHO6T1 and pHO6N1 that contains the mutant and normal $\mathrm{H}$-ras gene respectively, into the human cell line HeLa, by the calcium phosphate technique. It was found that the mutant $\mathrm{H}$-ras gene enhances the activity of the $\mathrm{Rb}$ gene promoter in contrast to the normal $\mathrm{H}$-ras gene that inhibits it. The expression of the CAT gene in stable clones of HeLa cells carrying the promoter of $\mathrm{Rb}$ gene after treatment with TPA and EGF respectively, was also investigated, whereas TPA enhanced, EGF had no effect on the activity of the $\mathrm{Rb}$ gene promoter.
\end{abstract}

\section{Introduction}

The $\mathrm{Rb}$ gene was the first human tumor suppressor gene isolated and is located on the long arm of human chromosome 13 (1-3). This gene contains 27 exons dispersed within $200 \mathrm{~Kb}$ of genomic DNA (4) and expresses a $4.7 \mathrm{~Kb}$ mRNA transcript in all normal tissues (2). Negative regulation of the cell cycle by $\mathrm{Rb}-1$ was implied from the model proposed by Kundson (5) who predicted that retinoblastoma arose after the mutation of both alleles of Rb-1. The product encoded by $\mathrm{Rb}$ gene is a nuclear protein found in phosphorylated and unphosphorylated states (6). The p110 is complexed by large T antigen (7), E7 (8) and E1 a (9) transforming proteins of SV40, adenovirus and human papilloma virus, respectively.

Cancer cells become tumorigenic as a result of multiple independent steps (for review see ref. 10) which subvert the

Correspondence to: Professor D.A. Spandidos, Institute of Biological Research and Biotechnology, National Hellenic Research Foundation, 48 Vas. Constantinou Ave., Athens, 11635 , Greece

Key words: Rb gene, ras oncogene, phorbol esters, epidermal growth factor normal growth control mechanisms. Some of these steps have been linked with mutations that either activate protooncogenes such as ras and $m y c$, or remove the inhibitory action of tumor-suppressor genes such as Rb and p53. In spite of their importance in the mechanism of carcinogenesis, little is known about the normal functions of ras and $\mathrm{Rb}$.

The members of the ras family, Harvey $(\mathrm{H})$, Kirsten $(\mathrm{K})$ and N-ras genes, code for GTP binding proteins of 21,000 daltons (ras $\mathrm{p} 21$ ). Ras $\mathrm{p} 21$ shares sequence homology with $\mathrm{G}$ proteins which are known to be signal transducers and they are associated with the inner surface of the plasma membrane and exhibit GTPase activity (11). The product of the different ras genes are thought to play a role in transduction of external signals towards an intracellular target. These proteins bind GTP and posses an intrinsic GTPase activity implicated in the regulation of their activity (12). A model has been suggested (13) where p21 mediates a signal to intracellular targets after it has received another signal from a growth factor through its receptor. It is interesting to note in this connection that EGF, which has the same receptor as a TGF, stimulates $\mathrm{p} 21$ to bind GTP (14).

Phorbol esters such as TPA (12-O-tetradecanoylphorbol13 -acetate) are tumor promoters which are capable of potentiating the effect of an initiating carcinogen. It is thought that they exert their biological effect by altering gene expression through a process which involves the activation of protein kinase $C$ (15). Relevant to this hypothesis is the finding that TPA induces transcription of cellular protooncogenes, e.g. c-fos $(16,17)$, c-myc $(16,18)$ and c-sis (19). In an attempt to identify the target of transcription regulation by ras, we examined its effect on the promoter of the $\mathrm{Rb}$ gene, in expectation of activation of $\mathrm{Rb}$ transcription by ras. We also tested whether the Rb promoter could be activated by TPA and EGF. Our results show that mutant H-ras gene enhances the activity of the $\mathrm{Rb}$ gene promoter in contrast to the normal H-ras gene that inhibits it. TPA, was able to induce expression of a CAT gene linked to the human $\mathrm{Rb}$ promoter region, whereas EGF had no effect on the activity of the $\mathrm{Rb}$ gene promoter.

\section{Materials and methods}

Cells and plasmids. pRbCAT2 contains human Rb-1 promoter sequence between -1546 and +186 (relative to the major start site of transcription) linked to the chlor- 


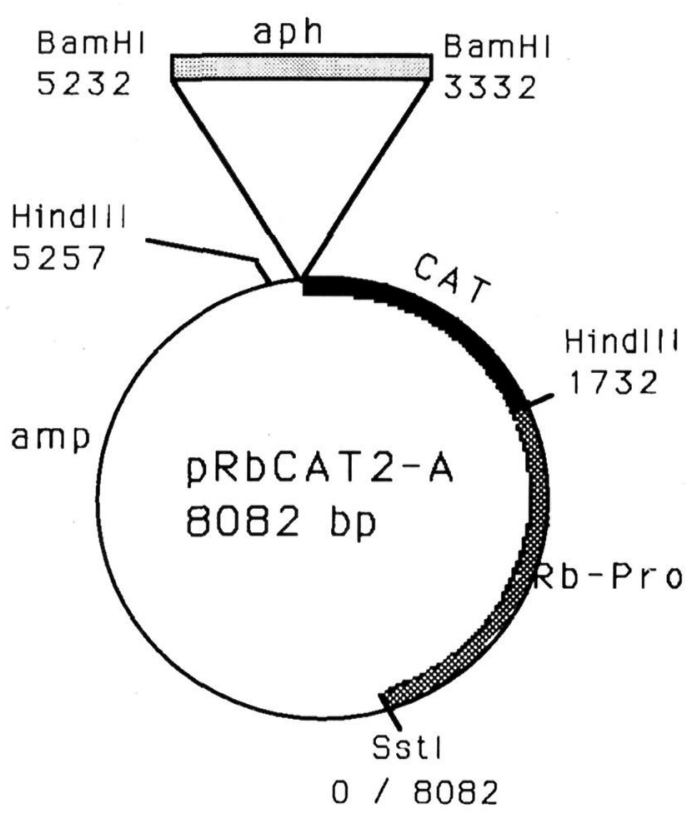

Figure 1. Plasmid pRbCAT2-A was constructed by ligation of the $1.9 \mathrm{~Kb}$ BamHI fragment of the aph gene into BamHI-digested plasmid pRbCAT2.

amphenicol acetyltransferase (CAT) gene (2). Plasmid $\mathrm{p}+53 \Delta \mathrm{CAT}$ is the $5^{\prime}$ deletion constract of pRbCAT2 (20). Plasmid p201 carry the aph gene and the CAT gene linked to the human mutant T24 H-ras promoter region (21). Plasmids pHO6T1 and pHO6N1 contains the $6.6 \mathrm{~Kb}$ of the mutant and normal $\mathrm{H}$-ras gene, respectively (22). Plasmid pRbCAT2-A carry the human Rb-1 promoter sequence between -1546 and +186 and linked to the CAT gene, the $1.9 \mathrm{~Kb}$ Bam HI fragment of the aph gene (Fig 1).

HeLa cells (ATCC CCL 2) were cultured in Dulbecco'sF12 medium supplemented with 10\% fetal calf serum.

DNA transfection and CAT assays. Transfections of HeLa cells with plasmid DNA were performed using a modification (23) of the calcium phosphate technique (24). Stable transfectants were isolated in the presence of 200 $\mu \mathrm{g} / \mathrm{ml}$ geneticin. For CAT assays, cells were grown exponentially in absence of geneticin. TPA was purchased from Sigma and 1000x stocks were made in DMSO. EGF was purchased from Collaborative Research Incorporation and $50 \mathrm{ng} / \mathrm{ml}$ stock was made in Dulbecco's-F12 medium. Cells in the presence or absence of TPA or EGF were harvested and assayed for CAT activity as previously described (25). HeLa cells were cotransfected by the calcium phosphate precipitation technique with $10 \mu \mathrm{g}$ of reporter constract and $30 \mu \mathrm{g}$ of each effector constract (pHO6T1, pHO6N1 and pHomer 6). All CAT assays were repeated at least twice and the reproducibility of the results was confirmed.

\section{Results}

Suppression of Rb transcription by the normal H-ras protein. In transient-expression assays using HeLa cells (Fig. 2) cotransfection of pRbCAT2 with the normal H-ras construct
HELA

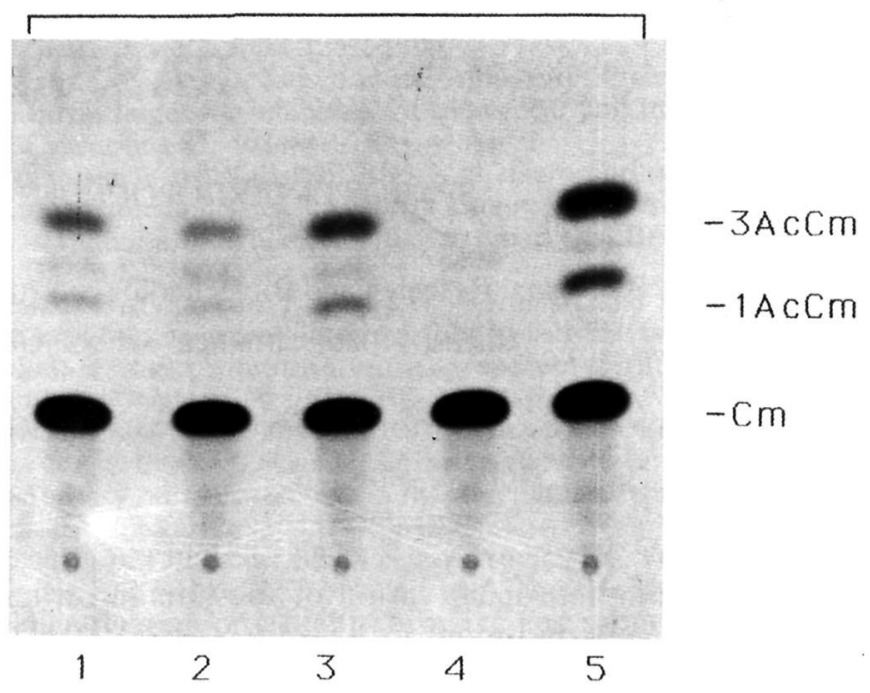

Figure 2. Effect of human H-ras on Rb transcription. pRbCAT2 (lanes 1-3) was cotransfected with pHomer 6 (lane 1), pHO6Nl (lane 2) and pHO6Tl (lane 3) into HeLa cells. Plasmids p+53 4 CAT (lane 4) and p201 (lane 5), negative and positive control, respectively, were transfected into HeLa cells.

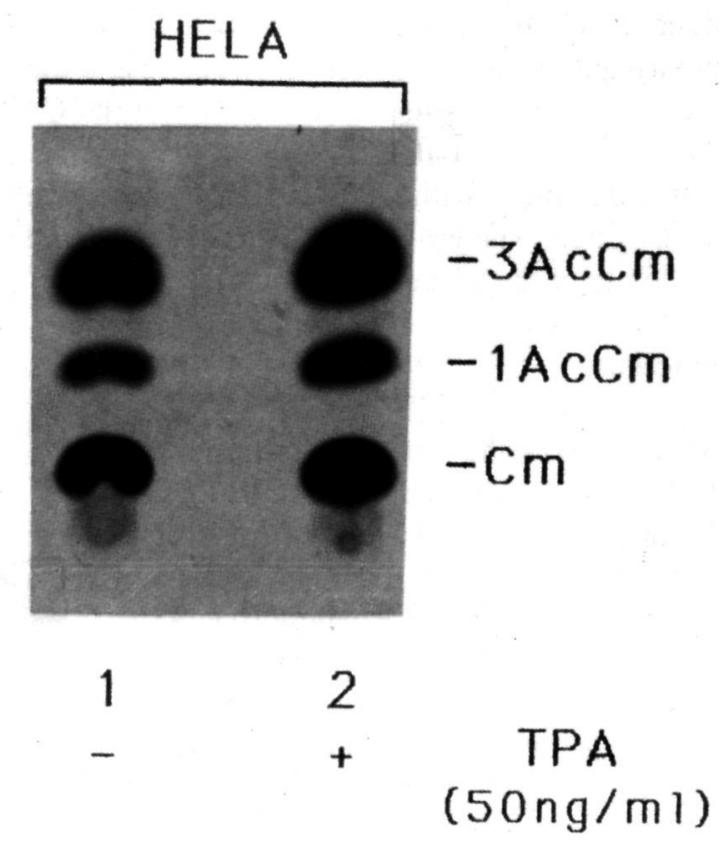

Figure 3. Chromatogram of representative CAT assays with extracts from transfectant HeLa pRbCAT2-A cells with $(50 \mathrm{ng} / \mathrm{ml})$ and without TPA treatment.

pHO6N1, resulted in less CAT activity than that on its cotransfection with pHomer 6 . In contrast, cotransfection of pRbCAT2 with the mutant $\mathrm{H}-$ ras construct pHO6T1, resulted in enhanced CAT activity. In two independent experiments, we observed an average of 3 -fold reduction and 2 -fold increase in CAT activity with the normal and mutant $\mathrm{H}-$ ras, respectively.

TPA increased, whereas EGF had no effect on Rb transcription. It was of interest to examine the responsiveness of $\mathrm{Rb}-1$ promoter to phorbol ester TPA. The possibility that the 


\section{HELA}

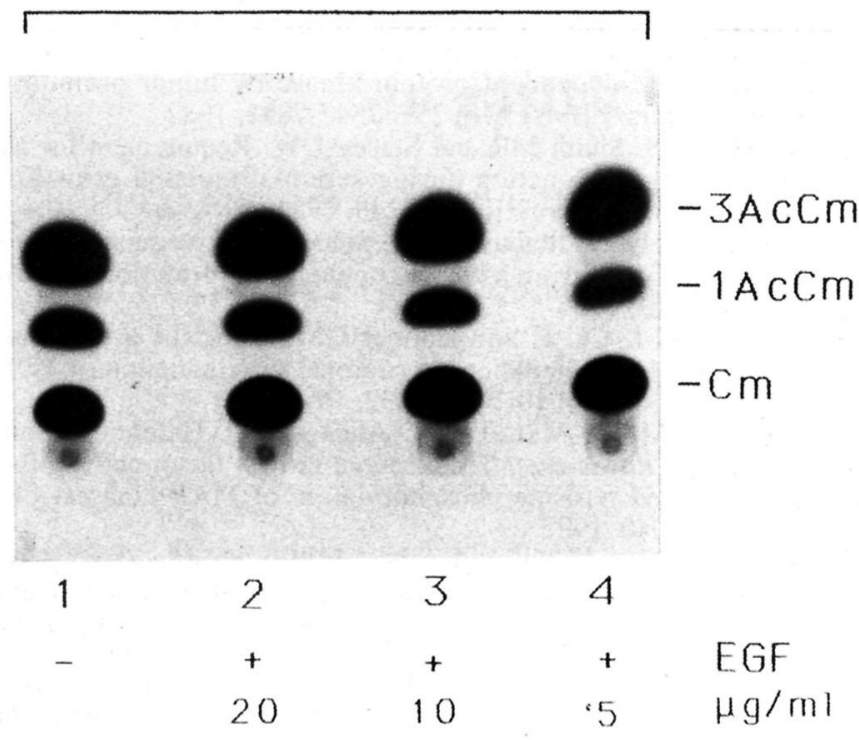

Figure 4. Chromatogram of representative CAT assays with extracts from transfectant HeLa pRbCAT2-A cells with $20 \mu \mathrm{g} / \mathrm{ml}$ (lane 2), $10 \mu \mathrm{g} / \mathrm{ml}$ (lane 3) and $5 \mu \mathrm{g} / \mathrm{ml}$ (lane 4) and without (lane 1) EGF treatment.

human $\mathrm{Rb}-1$ promoter could respond to the TPA was examined by treating stable transfectants carrying a CAT gene linked to the Rb-1 promoter. Transfectant cell line was obtained by transfecting plasmid pRbCAT2-A into recipient HeLa cells and selecting for geneticin resistance. Treatment with TPA was performed at various TPA concentrations and time intervals. At optimum conditions, that is, after $12 \mathrm{~h}$ exposure to $50 \mathrm{ng} \mathrm{TPA} / \mathrm{ml}$, CAT expression in $\mathrm{HeLa}$ RbCAT2-A transfectants which carried CAT plasmid linked to the $\mathrm{Rb}-1$ promoter was increased (2.3-fold) compared to untreated cells (Fig. 3). On the other hand HeLa cells transfected with the same plasmid did not respond to EGF (Fig. 4).

\section{Discussion}

The mechanism by which several transcription factors interact with the $\mathrm{Rb}$ promoter and trigger RNA synthesis, remains unknown. However, it is obvious that an important step towards understanding the regulation and function of the $\mathrm{Rb}$ promoter is the investigation of such interactions.

In this study we have shown that normal ras suppresses $\mathrm{Rb}$ transcription in contrast to mutated ras which enhances it. To our knowledge suppression or activation of the $\mathrm{Rb}$ transcription by the normal or the mutated ras gene, respectively has not so far been reported. However, it is known that mutated ras leads to phosphorylation of the p53 protein through activation of MAP-2 and casein kinase II (26). It has also been reported that the wild-type $\mathrm{p} 53$ protein suppresses the transcription of the $\mathrm{Rb}$ gene through a cisacting element mapped within the Rb promoter (20). Thus, we can suggest that mutated ras enhances the $\mathrm{Rb}$ transcription via phosphorylation and consequently inactivation of the p53 protein. Alternatively, the ras genes can influence the $\mathrm{Rb}$ transcription through activation of $r a f-1$ and MAP-2 kinase which can then activate both S6 kinase and DNA synthesis-promoting factor (SPF). SPF contains cyclin, p107, the transcription factor E2F and tumor suppressors such as the retinoblastoma gene product and p53 (26).

It is well known that stimulation of cell growth by TPA occurs through its direct interaction with protein kinase $\mathrm{C}$ (27). Also, it has been reported that TPA can induce expression of a CAT gene linked to the human $\mathrm{H}$-ras 1 promoter region (21). We found that TPA activates the transcription of $\mathrm{Rb}$ gene. This activation may be either a direct effect of the TPA on the Rb promoter, possibly through a TPA-responsive element or an indirect effect through activation of the mutated ras gene and subsequent activation of the $\mathrm{Rb}$ gene.

It has been found that many tyrosine kinases including the receptors for epidermal growth factor, nerve growth factor and insulin transmit intracellular signals through ras proteins (28-31). Ligand binding to such receptors stimulates ras guanine-nucleotide exchange activity (32-36) and increases the level of GTP-bound ras $(37,38)$. Whether EGF acts also through inhibition of the $\mathrm{Rb}$ gene has not been reported. In order to investigate this possibility we treated stable clones of HeLa cells carrying the Rb promoter with various concentrations of EGF. Our results show that EGF has no effect on the transcription of the Rb gene.

In conclusion, our results indicate that the transcription of the $\mathrm{Rb}$ gene may be regulated through normal and mutated ras as well as phorbol esters. Even if the suppression of the $\mathrm{Rb}$ transcription by normal ras or the activation by its mutated form seems to be a paradox, it may reflect an additional mechanism through which the cells avoid tumorigenesis.

\section{References}

1. Friend SH, Bernards R, Rojelj S, Weinberg RA, Rapaport JM, Albert DM and Dryja TP: A human DNA segment with properties of the gene that predisposes to retinoblastoma and osteosarcoma. Nature 323: 643-646, 1986.

2. Lee W-H, Bookstein R, Hong F, Young LJ, Shew J-Y and Lee EY-HP: Human retinoblastoma susceptibility gene: cloning, identification and sequence. Science 235: 1394-1399, 1987.

3. Fung YKT, Murphree AL, T'Ang A, Qian J, Hinrichs SH and Benedict WF: Structural evidence for the authenticity of the human retinoblastoma gene. Science 236: 1657-1661, 1987.

4. Hong FD, Huang H-JS, To H, Young L-J S, Oro A, Bookstein R, Lee EY-HP and Lee W-H: Structure of the human retinoblastoma gene. Proc Natl Acad Sci USA 86: 5502-5506, 1989.

5. Knudson AG: Mutation and cancer: Statistical study of retinoblastoma. Proc Natl Acad Sci USA 68: 820-823, 1971.

6. Lee WH, Shew JY, Hong F, Sery T, Donoso LA, Young LJ, Bookstein R and Lee EY-HP: The retinoblastoma susceptibility gene product is a nuclear phosphoprotein associated with DNA binding activity. Nature 329: 642-645, 1987.

7. DeCaprio J, Ludlow JW, Figge J, Shew J-Y, Huang C-M, Lee W-H, Marsilio E, Paucha E and Livingston DM: SV40 large tumor antigen forms a specific complex with the product of the retinoblastoma gene. Cell 54: 275-283, 1988.

8. Whyte P, Buchkovitch JJ, Horowitz JM, Fried SH, Raybuck M, Weinberg RA and Harlow E: Association between an oncogene and an anti-oncogene: the adenovirus E1A proteins bind to the retinoblastoma gene product. Nature 334: 124-129, 1988.

9. Munger K, Werness BA, Dyson N, Phelps WC, Harlow E and Howley PM: Complex formation of human papillomavirus E7 proteins with the retinoblastoma tumor suppressor gene product. EMBO J 8: 4099-4105, 1989. 
10. Spandidos DA: A unified theory for the development of cancer. Biosci Rep 6: 691-708, 1986.

11. Spandidos DA (Ed): Ras oncogenes. Plenum Press, New York and London, pp1-323, 1989.

12. Barcacid M: Ras genes. Annu Rev Biochem 56: 779-827, 1987.

13. Spandidos DA: Mechanism of carcinogenesis: The role of oncogenes, transcriptional enhancers and growth factors. Anticancer Res 5: 485-498, 1985.

14. Kamata T and Feramisco JR: Epidermal growth factor stimulates guanine nucleotide binding activity and phosphorylation of ras oncogene proteins. Nature 310: 147-150, 1984.

15. Nishizuka $Y$ : The role of protein kinase $C$ in cell surface signal transduction and tumor promotion. Nature 305: 693-698, 1984

16. Greenberg ME and Ziff EB: Stimulation of 3T3 cells induces transcription of the c-fos proto-oncogene. Nature 311: 433-438, 1984.

17. Kruijer W, Cooper JA, Hunter T and Verma IM: Plateletderived growth factor induces rapid but transient expression of the c-fos gene and protein. Nature 312: 711-716, 1984.

18. Kelly K, Cohran BH, Stiles CD and Leder P: Cell-specific regulation of the c-myc gene by lymphocyte mitogens and platelet-derived growth factor. Cell 35: 603-610, 1983.

19. Kolamonici OR, Trepel JB, Vidal CA and Neckewrs LM: Phorbol ester induces c-sis gene transcription in stem cell line K-562. Mol Cell Biol 6: 1847-1850, 1986.

20. Shiio Y, Yamamoto $T$ and Yamaguchi N: Negative regulation of $\mathrm{Rb}$ expression by the $\mathrm{p} 53$ gene product. Proc Natl Acad Sci USA 89: 5206-5210, 1992.

21. Spandidos DA, Nichols RAB, Wilkie NM and Pintzas A: Phorbol ester-responsive $\mathrm{H}$-ras 1 gene promoter contains multiple TPA-inducible / AP-1-binding consensus sequence elements. FEBS Lett 240: 191-195, 1988.

22. Spandidos DA and Wilkie NM: Malignant transformation of early passage rodent cells by a single mutated human oncogene. Nature 310: 469-475, 1984.

23. Spandidos DA and Wilkie NM: Expression of exogenous DNA in mammalian cells. In: In Vitro Transcription and Translation A Practical Approach. (Hames BD and Higgins SJ eds) pp. 148, IRL Press, Oxford 1984.

24. Graham FL and Van der EB AJ: A new technique for the assay of infectivity of human adenovirus 5 DNA. Virology 52: 456463, 1973.

25. Spandidos DA and Riggio M: Promoter and enhancer-like activity at the 5 '-end of normal and T-24 Ha-ras 1 gene. FEBS Lett 203: 169-174, 1986.
26. Berridge MJ: Inositol triphosphate and calcium signaling. Nature 361: 315-325, 1993.

27. Castagua M, Takai Y, Kaibuchi K, Sano K, Kikkawa U and Nishizuka Y: Direct activation of calcium-activated, phospholipid-dependent protein kinase by tumor-promoting phorbol esters. J Biol Chem 257: 7847-7851, 1982.

28. Mulcahy LS, Smith MR and Stacey DW: Requirement for ras proto-oncogene function during serum-stimulated growth of NIH3T3 cells. Nature 313: 241-248, 1985.

29. Smith MR, DeGudicibus SJ and Stacey DW: Requirement for c-ras proteins during viral oncogene transformation. Nature 320: 540-543, 1986

30. Szeberenyi J, Cai H and Cooper GM: Effect of a dominant inhibitory Ha-ras mutation on neuronal differentiation of PC12 cells. Mol Cell Biol 10: 5324-5332, 1990.

31. Thomas SM, De Marco M, D'Ancagelo G, Halegoua S and Brugge JS: Ras is essential for nerve growth factor and phorbol ester-induced tyrosine phosphorylation of MAP kinases. Cell 68: 1031-1040, 1992.

32. Medema RH, de Vries-Smits AMM, van der Zon GCM, Maassen JA and Bos JL: Ras activation by insulin and epidermal growth factor through enhanced exchange of guanine nucleotides on p21 ras. Mol Cell Biol 13: 155-162, 1993.

33. Zhang K, Papageorge AG and Lowy DR: Mechanistic aspects of signaling through ras in NIH3T3 cells. Science 257: 671-674, 1992.

34. Burgering BM: Insulin stimulation of gene expression mediated by p21 ras activation. EMBO J 10: 1103-1109, 1991.

35. Li B-Q, Kaplan D, Kung H-F and Kamata T: Nerve growth factor stimulation of the ras-guanine nucleotide exchange factor and GAP activities. Science 256: 1456-1459, 1992.

36. Buday L and Downward J: EGF regulates the exchange rate of guanine nucleotides on p21ras in fibroblasts. Mol Cell Biol 13: 1903-1910, 1993.

37. Gibbs JB, Marshall MS, Scolnick EM, Dickson RAF and Vogel US: Modulation of guanine nucleotide bound to ras in NIH3T3 cells by oncogenes growth factors and the GTPase activating protein (GAP). J Biol Chem 265: 20437-20442, 1990.

38. Satoh T: Accumulation of p21ras in response to stimulation with epidermal growth factor and oncogene products with tyrosine kinase activity. Proc Natl Acad Sci USA 87: 79267929, 1990. 